\title{
Education and social protection policies in OECD countries: Social stratification and policy intervention
}

Journal of European Social Policy 23(5) 487-503

(C) The Author(s) 2013

Reprints and permissions:

sagepub.co.uk/journalsPermissions.nav DOI: 10.1 | 77/109589287|3499|74

esp.sagepub.com

@SAGE

\section{Miroslav Beblavý}

The Centre for European Policy Studies, Belgium and Comenius University, Slovakia

\section{Anna-Elisabeth Thum}

The Centre for European Policy Studies, Belgium

\section{Marcela Veselkova}

Slovak Governance Institute, Slovakia

\begin{abstract}
We examine the relationship between education and social protection policies across OECD countries and thereby contribute to the growing political and academic discussion on how social investment and social protection are interrelated. We focus on how government policy in two policy domains (education, social protection) affects social stratification. The paper is based on a principal methodological innovation, which lies in disaggregating the ways in which policy-makers influence stratification into two distinct dimensions: one is concerned with how much the state intervenes in the provision of education/social protection and how much it leaves to individual, family and market, and the second is concerned with the bias towards equality or stratification found in the state system itself. We find that countries can be grouped into a distinct number of education-social protection typologies, which differ from traditional clusterings and could indicate the need for multi-faceted pan-European education policies that take into account the longstanding differences in stratification as opposed to one-size-fits-all policy initiatives.
\end{abstract}

\section{Keywords}

PISA, school-level socio-economic gradients, stratification, trade-off thesis, welfare typology

In this paper, we analyse the relationship between education and social protection policies across OECD countries and thereby contribute to the large discussion on how social investment and social protection are interrelated. ${ }^{1}$ We focus on how government policy

\section{Corresponding author:}

Miroslav Beblavý, The Centre for European Policy Studies, I

Place du Congres,

Brussels, B-1000, Belgium.

Email: miroslav.beblavy@ceps.eu 
in two policy domains (education, social protection) affects stratification. Our principal methodological innovation is in disaggregating the ways in which policy-makers influence stratification into two distinct dimensions. The first one is concerned with how much the state intervenes in the provision of education/social protection and how much it leaves to the individual, the family and the market. The second dimension is concerned with the bias towards equality or stratification found in the state system itself.

The paper shows a stark difference in approaches to education stratification in Central European countries compared with the Anglo, Nordic and (surprisingly) Southern European models. Furthermore, we identify clusters that appear to be based rather on historical and geographical links transcending the Iron Curtain than on classical welfare regimes.

We also examine whether, in a given country, similar policy choices with regard to stratification prevail in education and social protection system or the opposite (trade-off) is the case. We find that different countries answer this question in different ways, but our results show that only a limited number of combinations explain the situation in most countries. These results show that using this methodology produces clustering of countries different from the traditional Esping-Andersen's (1990) typology.

We test the two premises above by a cluster analysis, which we perform with state-of-the-art methodology. The methodology used is seen as superior to other methodologies as it is based on statistical criteria determining the choice of the type and of the number of clusters in the data. Our paper also incorporates several new EU member states from the post-communist Europe, which is rare. We selected pension policy as a proxy for wider social protection policies (the reasoning for this choice is presented in the next section).

The remainder of the paper is organized as follows: in the next section, we review the literature on dimensions of stratification and explain our choices of variables and overall approach. The subsequent methodological section presents details on the clustering methodology used and its fine points. The final two sections present results and conclusions.

\section{Dimensions of stratification}

\section{The role of education and social protection policies in stratification}

The academic analysis of social policy recognizes that existing social policies hierarchically stratify individuals or groups of people. In The Three Worlds of Welfare Capitalism, Esping-Andersen (1990) conceptualizes stratification along three dimensions, namely the corporatist and etatist, the liberal and the socialist dimension. Based on the scores for each characteristic around 1980, Esping-Andersen (1990) identifies three ideal regime types on the stratification dimension. The historical and continued utility of the Three Worlds typology is questioned by recent replication studies (for revision of welfare stratification, see Hicks and Kenworthy, 2003; Scruggs and Allan, 2008; Scruggs and Pontusson, 2008).

Education was the most neglected area in the comparative welfare literature. On the one hand, public education predated the social legislation (Iversen and Stephens, 2008: 602); on the other hand it was also viewed as 'different' from social policies (Wilensky, 1975: 3) - whereas education policy addresses the equality of opportunities, social policy addresses equality of outcomes. There is a growing body of literature that examines educational policies through a welfare lens. This is done either from the perspective of expenditure (Ansell, 2008; Hega and Hokeinmeier, 2002; Pechar and Andres, 2011), equality (Allmendinger and Leibfried, 2003; Peter et al., 2010) or both (Willemse and de Beer, 2012). These scholars build their argument on the trade-off thesis, which posits that social and educational policies compete for the public sector funding support (Castles, 1989; Heclo, 1985; Heidenheimer, 1981). As education and social security programmes are viewed as alternative strategies, countries invest either in educational opportunities or in social insurance programmes to ensure equality of conditions (Heidenheimer, 1981: 269). Education policies can thus be viewed as preventive and prospective, whereas social policies are seen as retrospective and compensatory (Allmendinger and Leibfried, 2003). Empirical examinations of spending patterns on education and social insurance programmes suggest that welfare states with similar social insurance policies will also cluster according to 
the similarity of their education policies (Hega and Hokenmeier, 2002). However, the trade-off thesis seems to hold only for liberal and conservative regimes (Pechar and Anders, 2011). Although the exploration of educational models in terms of social expenditure is necessary to understand the evolution of governmental support for various educational models, this focus underemphasizes how educational policy structures social relations (Esping-Andersen, 1990: 58). Stratification is addressed by Peter et al. (2010), who suggest existence of distinct clusters also when looking at the equality of educational opportunities: variation in the socio-economic composition of a school has the greatest impact on student achievement in conservative regimes and the least in socialdemocratic regimes.

Alternatively, the trade-off thesis might be explained by the intra-generational and/or intergenerational conflict, in which classes and/or age cohorts compete for scarce resources. Busemeyer et al. (2009) find that individual preferences for redistributive social policies are stratified by both socioeconomic position (income) and individual's position in the lifecycle (age). The magnitude of age cleavage varies across policy fields, with the strongest (negative) age effects to be found in the case of education spending. The variation among countries does not correspond directly to the welfare regimes. However, Montolio and Piolatto (2011) show that voters anticipate the positive effect of education on future pensions: the support for a publicly financed education system increases, the more redistributive the pension system is.

In contrast to the trade-off thesis, the varieties of capitalism approach championed by Hall and Soskice (2001) suggests that social protection and educational spending are complements to distinct modes of national production regimes (Estevez-Abe et al., 2001). High social protection characteristic of coordinated market economies serves as an incentive for workers to invest in specific, vocational skills. As the skills composition of the work force navigates production into 'diversified quality production' (Streeck, 1991) employers will join skilled workers in supporting social protection and training policies that maintain the high skill equilibrium. In contrast, workers in liberal market economies with low social protection will be less willing to invest in specific skills and will favour training in general, portable skills. Iversen and Stephens (2008) extend this argument to the entire educational system and distinguish three distinct worlds of human capital formation. However, the link towards stratification, which is at the core of our interest, is ambiguous. Iversen and Stephens (2008) argue that social equality fosters high levels of human capital (both general and specific skills) especially at the bottom end of the skill distribution, which in turn reinforces social equality. However, vocational training is a doubleedged sword for the poor. Although it boosts wages at the lower end of the income distribution, it at the same time precludes advances up the career ladder, when such training, especially in tracked systems, limits access to university (Ansell, 2010: 150).

In contrast to social policies, which alter social relations via access to and equality of social benefits, educational policies replicate or restructure existing social order by moderating equal access to education. Equality of educational opportunities is important because it is a determinant of subsequent life chances, namely future earnings (Altonji and Pierret, 2001; Ashenfelter et al., 1999; Bishop, 1992) and wealth and health in later life (Deaton and Paxson, 1998; O'Rand, 2002).

Persistent, albeit declining, inequality of educational opportunities is well documented (for review of the relevant literature, see Breen and Jonsson, 2005) and raises two interrelated questions. First, what are the mechanisms that link social origins to educational outcomes, and second, what factors explain the cross-national variance in educational inequality. On the micro-level, the social differentials in educational attainments are attributed to cost-benefit analysis of additional schooling (Breen and Goldthorpe, 1997; Gambetta, 1987). However, the payoff matrices are sensitive to institutional context: perceived costs of an education or the probabilities of succeeding at university may differ according to the organization of schooling (Breen and Jonsson, 2005: 227-8; Kerckhoff, 1995; Pfeffer, 2008). Inequality of student performance is associated with selection within educational systems, especially the timing and rigidity of student selection. The sooner the students are tracked, the greater the dependence of the student performance on family background 
(Hanushek and Woessmann, 2006; Organisation for Economic Co-operation and Development, 2010; Pfeffer, 2008; Schuetz et al., 2008; Woessmann, 2009). We can thus classify educational systems according to the degree of stratification (Pfeffer, 2008: 553; Shavit and Müller, 1998). The resulting clusters (Peter et al., 2010; Pfeffer, 2008) loosely correspond to the welfare regimes.

The final dimension of stratification is gender (Bambra, 2006; Lewis, 1992; Sainsbury, 1994). The welfare burden assumed by families is an important source of educational choices and educational stratification. Estevez-Abe et al. (2001) suggest that in the absence of protection against dismissal, such as maternity, parental and family leave policies, and income maintenance during leaves, women are more likely than men to invest in general skills and prefer occupations where there are few men. Equality of educational opportunities is mediated also by availability of institutional childcare. The greater enrolment in early childcare and education is correlated with a lower influence of socio-economic background on students' later educational achievement (Berlinski et al., 2009; Causa and Chapuis, 2010; Esping-Andersen, 2004; Leuven et al., 2010; Schuetz et al., 2008). These findings can be interpreted in the light of the theory of formation of skills as a lifecycle process (Cunha and Heckman, 2007), which posits that skills acquired at one stage are inputs into the learning process of the next stage. However, whereas rates of return to investment in early education tend to be higher for children from disadvantaged families, at older ages they tend to be higher for children from families with higher socioeconomic status (Cunha and Heckman, 2007). School resources - such as learning time or extracurricular activities - are a key factor in determining the link between socio-economic background and educational performance (Organisation for Overseas Co-operation and Development, 2010: 78). Educational policies are thus able to intervene in the stratification process by counterbalancing a non-learning friendly environment for the child at home.

In other words, policy can intervene in the stratification through state provision or not intervene at all by leaving more space in a given area for an individual, family and market.

In the state system, policy settings determine what is the bias towards stratification in the system itself. As a result, we disaggregate the stratification impact of policies in social protection and education into two dimensions described in more detail below.

This also helps to answer the question why we chose pensions as an acceptable proxy for the social protection system as a whole in this case. The question is not whether education/pensions is an acceptable combination, but whether this combination is appropriate/suitable to the particular question we have in mind and whether the result adds something interesting to the stock of knowledge. We are interested in disaggregating stratification in education and social protection policies into the two dimensions, because we think that can provide interesting and different answers than other typologies that tend to either: fuse the two dimensions into one or ignore one of them. Then the choice of pensions to compare with education can be justified on both theoretical and practical grounds. On theoretical grounds, the clustering technique works best/most clearly in answering our question if the clustering happens across two domains, because then the complementarities/trade-offs between the two are uncovered/ most visible. If we included more domains on the welfare side - for example, health and labour market policy, then the clustering would reflect best fit between all domains - education and various domains of the welfare state (pensions, health, labour markets) which would actually be more of a muddle. In health and labour market policies, the disaggregation does not necessarily go into these two dimensions in which we are interested. On practical grounds, pension policy presents a choice of indicators that can easily measure both dimensions (which are not straightforward in labour markets or health).

\section{Boundaries of state provision}

In this section, we explain which indicators we selected to measure stratification-relevant boundaries of the state provision in pensions and education. With few exceptions (Esping-Andersen, 1990; Oesch, 2008), most scholars of pension systems take the Bismarckian/ Beveridgean dichotomy as the starting point of their analysis (Bonoli, 2003; Hinrichs, 2001; Myles and Pierson, 2001; Myles and Quadango, 1996). In an ideal Beveridge system, the universal flat-rate benefits equalize income upon retirement. In contrast, the 
benefits in the Bismarckian regime are earningsrelated and as such reproduce income differentials.

To control for 'stratification impacts of private pension solutions' (Ebbinghaus and Gronwald, 2011) we control also for the pension replacement rate of the median earner. This indicator measures to what extent the state provides pensions as opposed to the market or other private sources. It corresponds to EspingAndersen's (1990) 'private pension' variable, which was the proxy of the liberal dimension of stratification.

To determine the degree to which either the state or the market or family provide learning environments, we study participation in institutional childcare, the average number of hours spent at school per year and the average number of weekly hours spent in lessons out of school. For the time spent in lessons outside school we use the average time as well as the variance in time spent in lessons outside school.

\section{Stratification within the state system}

In this section, we explain the choice of indicators for measuring stratification within state-run pension and education policies.

To measure the extent to which pensions are stratified in the state system, that is, earnings-related, we rely on two indicators. The first indicator shows the ratio between the pensions of an individual who earned an income twice as high as the median earner and the pensions of a median earner. The second indicator shows the ratio between pensions of the median earner and the pensions of an individual who earned half the income of the median earner.

In terms of the education system, we choose two variables to measure the explicit stratification within the state-organized system: variance between schools (level of effective streaming) and variance of outcomes within schools when measured by different reading ability groups at the age of 15 years. Withinschool variance is measured as the part of the variance in reading performance explained by the withinschool variation and - accordingly - between-school streaming is measured by the part of the variance in reading performance explained by between-school variation. These variables indicate how far a country displays large differences in performance within and across schools. A high between-school variance in reading performance indicates that pupils of different reading capacity are to a large extent streamed into different schools. A high within-school variance in reading performance indicates that societal differences play out within schools and that schools have mixed pupils in terms of reading performance. We use these two measures together, because they provide a picture of total variance in the system as well as its disaggregation. Consequently, countries that have a high overall variance will not be clustered with countries with a low overall variance even if they have similar values on one of the two dimensions. This can be seen in practice in Table 3, where there are clusters with similar values for the STR2 indicator, but different STR1 values and vice versa.

\section{Data and methodology}

Table 1 lists the set of indicators that will enable us to explore whether countries deliberately intervene on both education and pensions or whether there is a trade-off between education and pensions. We select data from different sources - the PISA dataset, the OECD database and Eurostat. We choose the most recent available years, which range from 2009 to 2011. Our sample consists of 22 countries (for summary statistics see Table A1): Austria (AT), Belgium (BE), Czech Republic (CZ), Denmark (DK), Estonia (EE), Finland (FI), Germany (DE), Greece (GR), Hungary (HU), Iceland (IS), Ireland (IE), Italy (IT), Japan (JP), Luxemburg (LU), Netherlands (NL), Norway (NO), Poland (PL), Portugal (PT), Slovenia (SI), Spain (ES), Sweden (SE) and the United Kingdom (UK). The sample size was limited by data availability.

To detect clusters of countries in terms of stratifying policies we use two different clustering techniques: agglomerative hierarchical clustering with p-values and model-based clustering with a model selection strategy. ${ }^{2}$ Together the two methodologies give a picture of both reliable and tentative clusters (for an overview of advantages and disadvantages of each technique, refer to Danforth, 2010 or Fraley and Raftery, 1998).

Agglomerative hierarchical clustering is based on distance measures between data points and is a widely used method to discern clusters without predetermining the number of clusters beforehand. In agglomerative hierarchical clustering the data is first 
Table I. Indicator descriptions and sources.

\begin{tabular}{|c|c|c|}
\hline Indicator & Description & Source \\
\hline \multicolumn{3}{|l|}{ Education stratification } \\
\hline $\begin{array}{l}\text { Variance between } \\
\text { schools (STRI) }\end{array}$ & $\begin{array}{l}\text { Variance in student performance between schools } \\
\text { (measured on the reading scale), expressed as } \\
\text { a percentage of the average variance in student } \\
\text { performance across OECD countries. }\end{array}$ & PISA (2009) \\
\hline $\begin{array}{l}\text { Variance within schools } \\
\text { (STR2) }\end{array}$ & $\begin{array}{l}\text { Variance in student performance within schools } \\
\text { (measured on the reading scale), expressed as } \\
\text { a percentage of the average variance in student } \\
\text { performance across OECD countries. }\end{array}$ & PISA (2009) \\
\hline \multicolumn{3}{|l|}{$\begin{array}{l}\text { Learning environment } \\
\text { provision }\end{array}$} \\
\hline $\begin{array}{l}\text { Early childhood } \\
\text { education (LEI) }\end{array}$ & $\begin{array}{l}\text { Participants in institutional childcare or ISCED } 0-1 \text { at } \\
\text { ages } 3-5 \text { years; average of ranked values }\end{array}$ & EUROSTAT $(2008 / 2009)$ \\
\hline $\begin{array}{l}\text { Hours spent at school } \\
\text { (LE2) }\end{array}$ & $\begin{array}{l}\text { Weighted sum over hours per year of total } \\
\text { compulsory and non-compulsory instruction time in } \\
\text { the curriculum for } 7-8-, 9-11-, 12-14 \text {-year-olds }\end{array}$ & $\begin{array}{l}\text { OECD (2008), } \\
\text { 'Education at a Glance' }\end{array}$ \\
\hline $\begin{array}{l}\text { Extracurricular activity } \\
\text {-Mean (LE3) }\end{array}$ & $\begin{array}{l}\text { Average of out of school time lessons }(<2,2-4,4-6 \text {, } \\
>6 \mathrm{~h}) \text { in language, mathematics, science and other } \\
\text { subjects for } 7 \text { - to } 15 \text {-year-olds. }\end{array}$ & PISA (2009) \\
\hline $\begin{array}{l}\text { Extracurricular activity } \\
\text {-Variance (LE4) }\end{array}$ & $\begin{array}{l}\text { Variance of out of school time lessons }(<2,2-4,4-6 \text {, } \\
>6 \mathrm{~h}) \text { in language, mathematics, science and other } \\
\text { subjects for } 7 \text { - to I5-year-olds }\end{array}$ & PISA (2009) \\
\hline \multicolumn{3}{|l|}{ Welfare stratification } \\
\hline $\begin{array}{l}\text { Pension stratification I } \\
\text { (PENI) }\end{array}$ & $\begin{array}{l}\text { Ratio between replacement rate of the } 2 * \text { median } \\
\text { earner to the median earner }\end{array}$ & $\begin{array}{l}\text { OECD (20I I),'Pensions } \\
\text { at a Glance' }\end{array}$ \\
\hline $\begin{array}{l}\text { Pension stratification } 2 \\
\text { (PEN2) }\end{array}$ & $\begin{array}{l}\text { Ratio between replacement rate of the median earner } \\
\text { to the } 0.5^{*} \text { median earner }\end{array}$ & $\begin{array}{l}\text { OECD (20I I),'Pensions } \\
\text { at a Glance' }\end{array}$ \\
\hline \multicolumn{3}{|l|}{ Welfare provision } \\
\hline $\begin{array}{l}\text { Pension equalization } \\
\text { (PEN3) }\end{array}$ & Replacement rate of the median earner & $\begin{array}{l}\text { OECD }(201 \text { I I),'Pensions } \\
\text { at a Glance' }\end{array}$ \\
\hline
\end{tabular}

ISCED, International Standard Classification of Education.

divided into singleton clusters which are then merged to larger clusters in subsequent steps. We use Ward's method (based on the error sum of squares) and the Euclidean distance, which is the most commonly used method (Danforth, 2010: 12).

Model-based clustering is based on probability theory, and not on distance like hierarchical clustering techniques. Fraley and Raftery (1998) have developed a model-based clustering methodology in which each cluster is assumed to be a component of a normal mixture distribution. Their technique allows estimating a model in which the number of components of the normal mixture distribution (or equivalently the number of clusters) is unknown. They propose using a model selection technique to find out the optimal number of clusters as well as the optimal covariance structure. The selection process starts out with a maximum number of clusters (usually nine are set by the researcher) and a set of different covariance parameterizations. Using an $\mathrm{EM}^{3}$ technique parameters for each combination of covariance-model and number of components are estimated. Then, by negatively maximizing the Bayesian Information Criterion (BIC), from among these estimated models an optimal model for the normal mixture distribution is selected together with the optimal number of components or clusters and a set of parameters characterizing the normal mixture distribution. ${ }^{4}$

In order to perform both hierarchical clustering and model-based clustering techniques, we 
standardize the data, which eases the convergence of the algorithm used in model-based clustering. For model-based clustering we set a conjugate prior on the means and variances. ${ }^{5}$ Setting a prior eases the convergence of the algorithm and estimation of the posterior probabilities. We used the default of nine maximum possible clusters. For the hierarchical clustering with p-values, we set 1000 bootstrap replications.

\section{Results}

\section{Model-based clustering}

The results of model-based cluster analysis are shown in Table 2. The first column shows the clustering found by Esping-Andersen (1990) with the addition of a Mediterranean cluster (Bonoli, 1997; Ferrera, 1996; Ferreira and Figuereido, 2005) and a Central/Eastern European (CEE) country cluster (Fenger, 2007; Ferreira and Figuardo, 2005). The second and third columns show results of the clustering using pension and education indicators independently. The fourth column depicts the clustering obtained when taking the pension and the education measure set together. The fifth column illustrates the clustering results when looking at measures of explicit state intervention (streaming and pension replacement rate ratios). Finally, the sixth column shows clustering results when examining the extent to which the state system intervenes as opposed to the market or the family (participation in early childhood education, hours spent at school and hours spent in extracurricular activity). We understand this measure set as indicating the market-state boundary. Table 3 shows the associated means of the resulting clusters for all measure sets.

The clustering of the pension stratification data (column 2 in Table 2) shows that there are two main groups of countries: a large group of countries with a relatively high mean ratio between the replacement rates of low and high earners and a relatively high replacement rate for the mean earner (see Table 3) and a small group of egalitarian countries, namely the liberal countries Ireland and the UK, Belgium and the Czech Republic. Liberal countries have been characterized by Esping-Andersen (1990) as empowering the free market; there is some theoretical foundation to the fact that they would display an egalitarian state-provided pension system with low replacement rates in general. The Czech Republic is the only CEE country that has not yet undergone a state reform of the pension system.

The education clustering (column 3 in Table 2) suggests some modifications to the conclusions of Pfeffer (2009) and Peter et al. (2010). The first cluster shows a group of countries containing four of EspingAndersen's conservative countries (Germany, Austria, Belgium and the Netherlands), Italy and three CEE countries (the Czech Republic, Hungary and Slovenia). These countries can be classified as following the highly stratified Germanic education model, having quite a strong culture of streaming children into different schools and by a high exposure to stateprovided education (see Table 3 ).

The second cluster is a mixture of Scandinavian, Mediterranean and liberal countries, which display a relatively high degree of within-school variance in educational performance and a low degree of between-school variance. They can be classified as following models similar to the Anglo-Saxon, French or Scandinavian systems. The countries in this group are characterized by a weak culture of streaming and a high exposure to state-provided education.

The third cluster consists of three countries (Estonia, Greece and Poland) that are characterized by a quite low rank in participation rates in institutional childcare, a low degree of streaming into different schools and low numbers of hours spent at school, but a relatively high exposure to market-provided learning.

Japan constitutes the fourth cluster in the education clustering and is characterized by a high variance in reading performance both within and between schools, high participation in early childhood education, a high number of hours spent at school and a particularly high mean and variance in extracurricular activity. Japanese children are highly exposed to educational environments and variance in performance is high. The independence of Japan from other clusters seems mainly driven by high extracurricular activities.

By combining the education and pension measure sets (column 4 in Table 2), we aim to find out whether countries that intervene to a large extent in the stratification process in education also intervene strongly in the stratification process in pensions or whether 
Table 2. Model-based clustering results.

\begin{tabular}{|c|c|c|c|c|c|c|}
\hline Measure set & $\begin{array}{l}\text { Esping-Andersen } \\
\text { clustering }\end{array}$ & 'Pension' & 'Education' & $\begin{array}{l}\text { 'Education and } \\
\text { Pension' }\end{array}$ & $\begin{array}{l}\text { 'Streaming } \\
\text { and Pension' }\end{array}$ & $\begin{array}{l}\text { 'Learning and } \\
\text { Pension' }\end{array}$ \\
\hline $\begin{array}{l}\text { Variables in } \\
\text { the set }\end{array}$ & - & $\begin{array}{l}\text { PENI, PEN2, } \\
\text { PEN3 }\end{array}$ & $\begin{array}{l}\text { STR I, STR2, } \\
\text { LEI, LE2, LE3, } \\
\text { LE4 }\end{array}$ & $\begin{array}{l}\text { STR I, STR2, LEI, LE2, } \\
\text { LE3, LE4, PENI, PEN2, } \\
\text { PEN3 }\end{array}$ & $\begin{array}{l}\text { STRI, STR 2, } \\
\text { PENI, PEN2 }\end{array}$ & $\begin{array}{l}\text { LEI, LE2, LE3, } \\
\text { LE4, PEN3 }\end{array}$ \\
\hline No. of clusters & 5 & 2 & 4 & 3 & 4 & 3 \\
\hline \multirow{12}{*}{$\begin{array}{l}\text { No. of } \\
\text { observations }\end{array}$} & 22 & 22 & 22 & 22 & 22 & 22 \\
\hline & AT & AT & AT & AT & AT & AT \\
\hline & $\mathrm{BE}$ & $\mathrm{DE}$ & $\mathrm{BE}$ & $\mathrm{DE}$ & DE & $\mathrm{BE}$ \\
\hline & $\mathrm{DE}$ & $J P$ & $C Z$ & GR & $\mathrm{HU}$ & $C Z$ \\
\hline & $J P$ & LU & $\mathrm{DE}$ & $\mathrm{HU}$ & IT & $\mathrm{EE}$ \\
\hline & LU & $\mathrm{NL}$ & $\mathrm{HU}$ & IT & NL & $\mathrm{FI}$ \\
\hline & NL & $\mathrm{EE}$ & IT & LU & SI & $\mathrm{DE}$ \\
\hline & & $\mathrm{HU}$ & NL & $\mathrm{NL}$ & & $\mathrm{HU}$ \\
\hline & $C Z$ & $\mathrm{PL}$ & SI & $\mathrm{SI}$ & $\mathrm{BE}$ & SE \\
\hline & $\mathrm{EE}$ & SI & & & $C Z$ & NO \\
\hline & $\mathrm{HU}$ & DK & DK & $\mathrm{BE}$ & $J P$ & PL \\
\hline & $\mathrm{PL}$ & $\mathrm{FI}$ & $\mathrm{FI}$ & $\mathrm{CZ}$ & & PT \\
\hline \multirow[t]{2}{*}{ Country } & $\mathrm{SI}$ & IS & IS & DK & IE & SI \\
\hline & & NO & LU & $\mathrm{EE}$ & UK & IE \\
\hline \multirow[t]{13}{*}{ Classifications } & DK & SE & NO & $\mathrm{FI}$ & & UK \\
\hline & $\mathrm{FI}$ & GR & PT & IS & DK & \\
\hline & IS & IT & ES & NO & $\mathrm{EE}$ & DK \\
\hline & NO & PT & SE & PL & $\mathrm{FI}$ & GR \\
\hline & SE & ES & $\mathrm{IE}$ & PT & GR & IS \\
\hline & & & UK & ES & IS & IT \\
\hline & ES & $\mathrm{BE}$ & & SE & LU & LU \\
\hline & GR & $C Z$ & & $\mathrm{IE}$ & NO & NL \\
\hline & IT & $\mathrm{IE}$ & $\mathrm{EE}$ & UK & $\mathrm{PL}$ & ES \\
\hline & PT & UK & GR & & PT & \\
\hline & & & $\mathrm{PL}$ & $\mathrm{JP}$ & ES & $J P$ \\
\hline & $\mathrm{IE}$ & & & & SE & \\
\hline & UK & & $\mathrm{JP}$ & & & \\
\hline
\end{tabular}

Note: As noted in Table I, PENI, PEN2 and PEN3 indicate different rates of replacement ratios across earning groups (between the $2 *$ median earner and the median earner (PENI), the median earner and the $0.5 *$ median earner (PEN2) and the replacement rate of the median earner (PEN3)), STRI indicates between school variance, STR2 within school variance (both STRI and STR2 are measured in \% of the average variance in student performance across OECD countries), LEI indicates participation in early childhood education (average of ranked values across age groups), LE2 hours spent at school (weighted sum over hours spent in schooling by different age groups), LE3 mean extracurricular activity and LE4 variance extracurricular activity (LE3 and LE4 are the mean and variance of the $\%$ of respondents).

there is a trade-off between pension and education policies. Countries can be clustered into three groups:

1. countries in which the state plays an important role and stratification is reproduced both in education and in pensions (mainly conservative countries, some CEE countries and Italy);

2. countries in which both the pension and the education system tend to be more egalitarian and the market plays a more important role 
Table 3. Cluster means for each measure set.

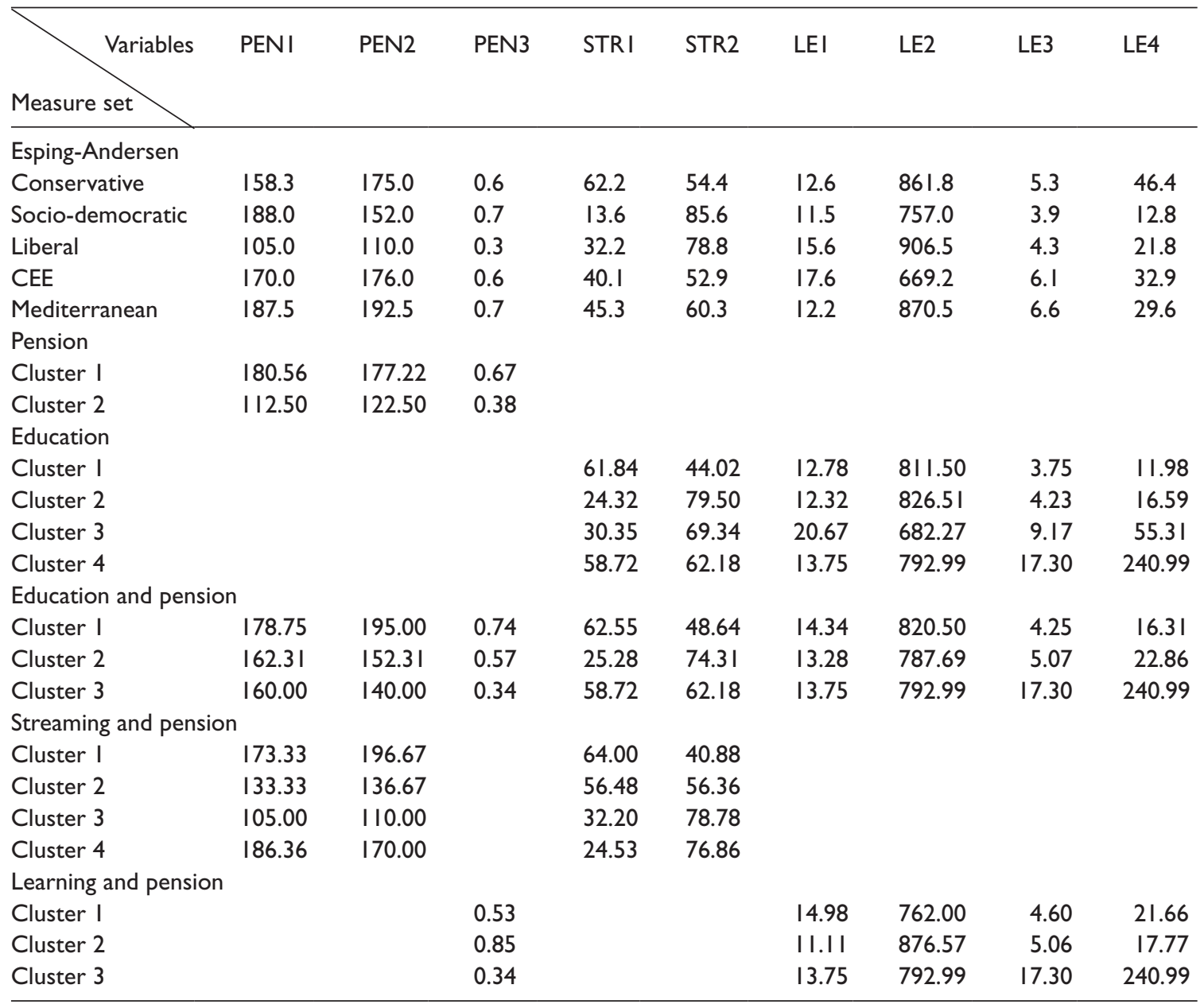

Note: As noted in Table I, PENI, PEN2 and PEN3 indicate different rates of replacement ratios across earning groups (between the $2^{*}$ median earner and the median earner (PENI), the median earner and the $0.5^{*}$ median earner (PEN2) and the replacement rate of the median earner (PEN3)), STRI indicates between school variance, STR2 within school variance (both STRI and STR2 are measured in \% of the average variance in student performance across OECD countries), LEI indicates participation in early childhood education (average of ranked values across age groups), LE2 hours spent at school (weighted sum over hours spent in schooling by different age groups), LE3 mean extracurricular activity and LE4 variance extracurricular activity (LE3 and LE4 are the mean and variance of the $\%$ of respondents).

(social-democratic, liberal, Mediterranean and some CEE countries);

3. Japan, which is characterized by a relatively egalitarian system in terms of pension stratification combined with a low replacement rate for the median earner, strong betweenand within-school variance and a particularly high amount of time spent in extracurricular activities.
Results from the education and the pension measure sets separately or jointly (the measure sets 'Education', 'Pension' and 'Education and Pension' in Table 2) all indicate that there is a cluster containing the more non-egalitarian countries and one displaying the more egalitarian countries.

In the next step (column 5 and 6 in Table 2) we split the measure sets into a set of variables measuring the explicit intervention of the state in the 
stratification process (pension stratification and school streaming policies) and a set of variables measuring the extent to which the state as opposed to the market provides learning environments (participation in institutional childcare, hours spent at school and hours spent in extracurricular activities).

Studying the measures of explicit state intervention (measure set 'Streaming and Pension', column 5 in table 2) we can see that countries can be roughly clustered into groups of either high or low equality in the pensions system combined with either high or low educational equality. The first group consists mainly of conservative countries, some CEE countries and Italy. It is characterized by non-egalitarian pensions and high educational inequality (a high degree of between-school streaming). The liberal countries form a separate group, characterized by low between-school streaming and a small difference in replacement rates of pensions for different earners. The Nordic and Mediterranean countries form another group, characterized by low levels of between-school streaming but high levels of stratification in the pensions. A fourth group consists of Belgium, the Czech Republic and Japan, characterized by both high within- and between-school streaming and an average level of stratification in the pension system.

The measure set indicating the extent to which the state intervenes as opposed to the market results in a clustering of two main groups and Japan (measure set 'Learning and Pension', column 6 in Table 2 ). The first group of countries seems to intervene less in the provision of pensions and education: provisions of pensions are lower, participation in institutional childcare and time spent at school are lower but non-state provided extracurricular activity is also low compared to the second group of countries. The second group of countries can be described as having a higher pension replacement rate, higher participation in institutional childcare, more hours spent in school and a somewhat higher degree of extracurricular activity. Japan is characterized by a small pension system (a low replacement rate to the median earner), relatively low participation in institutional childcare, relatively few hours spent at school and a high degree of extracurricular activity, indicating a more market-influenced system.
We can combine the findings of the fifth and the sixth column (columns 5 and 6 in Table 2 taken together) and group countries into those that are:

- less egalitarian in the stratification process and provide learning environments to a larger extent by the market - such as Austria, Germany, Hungary and Slovenia;

- less egalitarian in the stratification process and guarantee the provision of learning environments to a larger extent by the state - such as Italy and the Netherlands;

- more egalitarian in the stratification process and in which the state provides learning environments to a larger extent than the market such as Ireland and the UK;

- more egalitarian in the stratification process of education (but not of pensions) and leave the provision of learning environments to a larger extent to the state - such as Denmark, Greece, Iceland, Luxemburg and Spain;

- more egalitarian in the stratification process of education (but not of pensions) and leave the provision of learning environments to a larger extent to the market - such as Estonia, Finland, Norway, Poland, Portugal and Sweden.

The results from model-based clustering show that countries can to some extent be grouped into those that are egalitarian (these countries tend to be the social-democratic, liberal and Mediterranean countries) or non-egalitarian (these countries tend to be rather the conservative ones), in terms of stratification of both the pension system and the education system but some countries can also be egalitarian in one but not in the other dimension. In terms of education systems, the results show that countries fall into groups of more and less egalitarian education systems. The extent of state intervention in education can be high or low for egalitarian countries but only high for non-egalitarian countries.

Table 4 shows the BIC criteria for the selected models for all tested numbers of components.

\section{Agglomerative hierarchical clustering}

Results of the hierarchical clustering are generally similar to the results obtained from model-based clustering. 
Table 4. Bayesian information criteria for model-based clustering.

\begin{tabular}{|c|c|c|c|c|c|}
\hline Clusters & 'Pension' & 'Education' & $\begin{array}{l}\text { 'Education and } \\
\text { pension' }\end{array}$ & $\begin{array}{l}\text { 'Streaming and } \\
\text { pension' }\end{array}$ & $\begin{array}{l}\text { 'Learning and } \\
\text { pension' }\end{array}$ \\
\hline I & -197.1344 & -415.1709 & -584.6247 & -261.7103 & -333.3364 \\
\hline 2 & $-191.475^{a}$ & -402.1284 & -591.8372 & -253.6119 & -284.7932 \\
\hline 3 & -197.6752 & -397.3595 & $-567.5006^{a}$ & -259.2774 & $-282.3066^{a}$ \\
\hline 4 & -211.4415 & $-356.1928^{a}$ & -574.3125 & $-252.1089 a$ & -292.5433 \\
\hline 5 & -204.0313 & $-37 \mid .4133$ & -583.6482 & -266.269 & -303.5246 \\
\hline 6 & -218.7672 & -376.4892 & $-601.06 \mid$ & -271.4596 & -309.3842 \\
\hline 7 & -219.9995 & -382.4694 & -592.776 & $-272.7|3|$ & -317.7409 \\
\hline 8 & -228.7484 & -379.1933 & -584.8112 & -279.9109 & -334.5306 \\
\hline 9 & -236.0063 & -384.3335 & -918.4724 & -290.6201 & -338.0904 \\
\hline
\end{tabular}

Note:The Bayesian Information Criteria (BIC) are shown for the model of the covariance structure, which was selected as optimal (since it includes the maximized negative BIC value).

aMaximum value of the computed BIC.

They are presented in the form of dendrograms. We use a methodology that provides two types of special p-values indicating the statistical validity of a cluster. The green $\mathrm{p}$-values (they are found on the right side at each branch intersection and are called BP - 'bootstrap probability') are computed using a conventional bootstrap approach and indicate how often a certain cluster appears in each bootstrap run. The red p-values (they are found on the left side at each branch intersection and are called AU - 'approximately unbiased') are computed using a multi-scale bootstrap resampling technique and can be shown to be a more accurate approximation for unbiased p-values (Suzuki and Shimodaira, 2006).

Figure 1 shows the clustering that results when using the 'Education' measure set (including the streaming variables and the state- and market-provided learning environments). These results correspond to those of the model-based clustering (Table 2 column 3) - with the exception of Finland. The larger first cluster found using model-based clustering is further split when using hierarchical clustering: the Netherlands, Italy and Belgium are split into a separate cluster. As calculations of the group-specific means show (Table 3), the difference in participation in institutional childcare (which is higher in Belgium, the Netherlands and Italy) drives this further split of the first cluster when using hierarchical clustering.

The results of hierarchical clustering for the 'Education and Pension' measure set (including the education indicators and the indicators for stratification and size of the pension system) are again similar to the model-based clustering results in (Table 2 column 4) and the data are divided into more groups than in the model-based clustering. The large cluster of less egalitarian countries (both in the education and in the pension system) is now split into three different groups with Italy and the Netherlands being split off and Greece and Luxemburg being grouped with Portugal and Spain. Italy and the Netherlands have a relatively high non-egalitarian pension system compared with the other countries in the first cluster in the model-based clustering (see column 4, Table 2).

The second - more egalitarian - group of countries is also split into smaller groups in the hierarchical clustering results. Ireland, the UK, Belgium and the Czech Republic form their own cluster, probably due to their comparatively egalitarian pension system. Estonia and Norway form another separate group possibly because they are characterized by similarly low between-school streaming, high within-school streaming and high participation in institutional childcare - in which they are similar to Denmark, Iceland, Sweden and Finland (a Nordic model). They are also, however, characterized by a relatively high mean and variance in extracurricular activity - in which they are not similar to Denmark, Iceland, Sweden and Finland. Poland - the remaining country in the clusters on the right hand side of the dendrogram - is characterized similarly to the Nordic countries. 


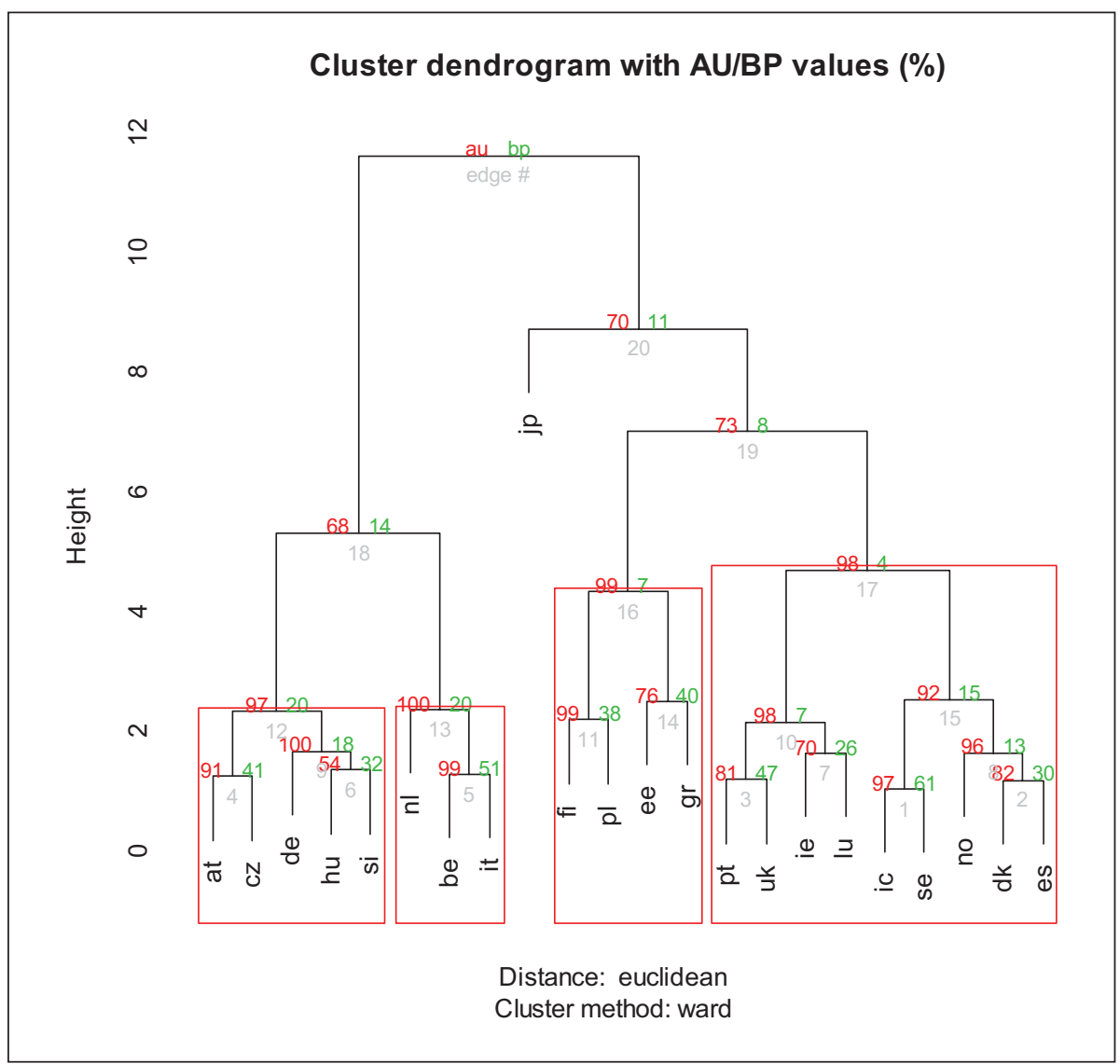

Figure I. Dendrogram with p-values for the measure set 'Education'.AU, approximately unbiased; BP, bootstrap probability.

The hierarchical clustering results for the indicators measuring the extent to which the state as opposed to the market provides learning environments: 'Learning and pension' is similar to the results in the model-based clustering, apart from Greece and Belgium, which have switched positions.

The results obtained from hierarchical clustering largely confirm those obtained by model-based clustering but offer a more nuanced picture by providing a set of further differentiated sub-clusters, which can be interpreted as being more tentative. All dendrograms as well as our dataset are available upon request.

\section{Conclusion}

In this paper we examined the relationship between education and social protection policies across OECD countries and thereby aimed to contribute to the growing academic and political discussion on how social investment and social protection are interrelated. In particular, we were interested in how government policies in both domains (education and social protection) affect social stratification. The paper is based on a principal methodological innovation, which lies in disaggregating the ways in which policy-makers influence stratification into two distinct dimensions. The first one is concerned with how much the state intervenes in the provision of education/social protection and how much it leaves to individual, family and market. The second dimension is concerned with the bias towards equality or stratification found in the state system itself.

The paper shows a stark difference in approaches to education stratification in Central European countries compared with the Anglo, Nordic and 
(surprisingly) Southern European models. Furthermore, we identify clusters that appear to be based rather on historical and geographical links transcending the Iron Curtain than on classical welfare regimes. This is important because it suggests multifaceted pan-European education policies that take into account the longstanding differences in stratification as opposed to one-size-fits-all policy initiatives.

We also examine whether, in a given country, similar policy choices with regard to stratification prevail in education and social protection system or the opposite (trade-off) is the case. We find that different countries answer this question in different ways, but our results show that only a limited number of combinations explain the situation in most countries.

The remainder of this section explains our cluster findings in detail - concentrating on each of the two distinct dimensions characterizing the ways in which policy-makers influence stratification (first, the degree of stratification found in the state system itself and second, the extent to which the state intervenes in the provision of social services) and finally taking both dimensions together.

\section{Clustering in terms of explicit stratification in the public system}

We find three different clusters. There are two pure types:

- with emphasis on equalization in both areas, present in the two Anglo-Saxon countries studied;

- with stratification in both, a cluster in which 'there is a proper place for everyone in society' and present in Germany and countries generally neighbouring Germany and historically influenced by its welfare and education policies, including several post-communist ones.

However, there are also mixed clusters. Particularly interesting is a large mixed cluster where equality in education policy is combined with stratification in pensions, something we could call 'equality of opportunity, not of outcomes'. This cluster combined Southern and Nordic countries.

The fourth option - equal pensions with a stratified education system seems to be rare and of a more random nature. Information on the four clusters is shown in Table 5.

\section{Clustering in terms of the extent of} public vs. family/market involvement

On the other hand, there is consistency between education and pension policies in terms of the extent of public vs. family/market involvement. With the exception of Japan, there are just two clusters.

The first cluster, which is more interventionist on both fronts (more school instruction time, more early childhood education, less variance on extracurricular lessons, higher pension replacement rates). It contains a mixture of Nordic and Southern countries, but it should be noted that only a minority of the Nordic countries is involved.

The second cluster, which is more family/marketdependent both in terms of pension and education, contains a combination of Germanic, Anglo-Saxon and Central Eastern European countries, but also several Nordic countries.

In this case, rather than the particular division of countries into clusters, we find the congruence between education and pension policies to be an intriguing one.

\section{Clustering in terms of combined dimensions}

We also explored clustering for the combined dimensions, where we wanted to know to what extent these two dimensions are orthogonal or correlated. Even though there does not appear to be a clear-cut relationship between the two dimensions, out of 16 possible combinations (since we have $2 \times 2$ matrix for each of the two dimensions) only five make an appearance:

- countries where stratification is reproduced both in public education and in pension systems even though the role of the state provision itself is limited (AT, DE, HU, SI);

- countries where both education and pension policy intervene in the stratification, but the role of state provision is limited in both (IE, UK);

- countries where the state plays an important role and stratification is reproduced both in education and in pensions (IT, NL);

- countries with trade-off between education and pension stratification in favour of educational intervention, but a strong role for state (DK, GR, IC, LU, ES); 
Table 5. Explicit stratification vs. equality in the public system.

\begin{tabular}{llll}
\hline & & Education & \\
\cline { 3 - 4 } & & Stratification & Equalization \\
\hline Pension & Stratification & AT, DE, HU, IT, NL, SI & DK, EE, FI, GR, IC, LU, NO, PL, PT, ES, SE \\
& Equalization & BE, CZ,JP & IE, UK \\
\hline
\end{tabular}

Source: Authors' compilation.

Table 6. Family/market vs. state provision in education and pension policy.

\begin{tabular}{ll}
\hline Type & Countries \\
\hline More interventionist in both & DK, GR, IC, IT, LU, NL, ES \\
More family/market-oriented in both & AT, BE, CZ, DE, EE, FI, HU, SE, NO, PL, PT, SI, IE, UK \\
Special case & JP \\
\hline
\end{tabular}

Source:Authors' compilation.

- countries with trade-off between education and pension stratification in favour of educational intervention and more family/market-oriented (EE, FI, NO, PL, PT, SE).

This indicates that while there is no clear correlation (positive or negative), the relationship is not completely random. Such a clustering of countries also provides mixed evidence on the trade-off thesis, which views education and social policies as alternative forms of social protection (Allmendinger and Leibfried, 2003; Castles, 1989).

Looking at the consistency of stratification patterns across policy domains, similarly to Scruggs and Allan (2006), Bambra (2006) or Scruggs and Allan (2008), our results challenge the conventional belief in existence of distinct welfare regimes.

There appears to be a single policy 'culture' across the two sectors with regard to the balance between state and private provision. In other words, countries do not combine different policies in education and welfare. However, on the stratification issue, there is much less consistency. While the core continental countries centred around Germany are consistently stratifying and the Anglo-Saxon countries consistently equalizing, most Southern and Scandinavian states combined stratification in pensions with equalization in education.
Our inclusion of post-communist countries also allows us to contribute to the original EspingAndersen's typology, which was based on history and lock-in of choices made during democratic capitalism in the first half of the 20th century and as such did not provide a theoretical foundation for explanation of diversity in the unified Europe. Our results are somewhat surprising in the sense that geography rather than common 'communist' heritage seem to determine the situation in post-communist countries. Central European countries lean towards Germany while Poland and the Baltics towards Scandinavia. We also show that the 'continental' type of welfare state is really not there; indeed there seems to be more overlap between Scandinavia and Iberia on one hand and the Central Europe and Italy on the other.

\section{Funding}

The work described in this paper was funded by the European Commission (project name NEUJOBS) through the Seventh Framework Programme (FP7). Grant Agreement No. 266833.

\section{Notes}

We would like to thank our reviewers for very helpful comments. 
1. Vandenbroucke, Hemerijk and Palier (2011) show that social investment and social protection are complements.

2. For the programming of these techniques we use the packages 'mclust' and 'pvclust' implemented in $\mathrm{R}$ version 2.12.2, an open source software available at http://cran.r-project.org/. Examples of the syntax employed can be downloaded on www.stat.washington.edu/research/reports/2012/tr597.pdf and http:// cran.r-project.org/web/packages/pvclust/pvclust.pdf.

3. An expectation-maximization algorithm is a procedure that produces maximum likelihood estimates of parameters in a statistical model.

4. The BIC for our models are shown in Table 4.

5. In the in-built $\mathrm{R}$ function 'mclust' the default is to set no prior; alternatively the function allows setting a conjugate prior (a prior from the same family as the posterior distribution). The in-built function does not specify any other type of prior that could be used. A conjugate prior usually ensures that there is a closedform solution for the posterior, which would otherwise need to be estimated by numerical integration. In our models estimation fails due to singularity of the covariance matrix if we set no prior. Alternative prior specifications are to set a prior only on the variance but not on the mean or to set other prior parameters for the conjugate prior. When specifying no prior on the mean, the same clustering result is found but the model for the covariance structure changes. When setting alternative prior parameters for the mean (the parameter for the prior on the mean is set to 0.01 by default), results are the same also in terms of the covariance structure.

\section{References}

Allmendinger, J. and Leibfried, S. (2003) 'Education and the Welfare State: The Four Worlds of Competence Production', Journal of European Social Policy 13(1): 63-81.

Altonji, J.G. and Pierret, C.R. (2001) 'Employer Learning and Statistical Discrimination', Quarterly Journal of Economics 116(1): 313-50.

Ansell, B. (2008) 'University Challenges Explaining Institutional Change in Higher Education', World Politics 60(2): 189-230.

Ansell, B.W. (2010) From the Ballot to the Blackboard: The Redistributive Political Economy of Education. Cambridge: Cambridge University Press.

Ashenfelter, O., Harmon, C. and Oosterbeek, H. (1999) 'A Review of Estimates of the Schooling/Earnings
Relationship, with Tests for Publication Bias', Labour Economics 6(4): 453-70.

Bambra, C. (2006) 'Decommodification and the Worlds of Welfare Revisited', Journal of European Social Policy 16(1): 73-80.

Berlinski, S., Galiani, S. and Gertler, P. (2009) 'The Effect of Pre-primary Education on Primary School Performance', Journal of Public Economics 93(1-2): 219-34.

Bishop, J.H. (1992) 'The Impact of Academic Competencies on Wages, Unemployment, and Job Performance', Carnegie-Rochester Conference Series on Public Policy 37: 127-94.

Bonoli, G. (1997) 'Classifying Welfare States: A Twodimension Approach', Journal of Social Policy 26(3): 351-72.

Bonoli, G. (2003) 'Two Worlds of Pension Reform in Western Europe', Comparative Politics 35(4): 399416.

Breen, R., Luijkx, R., Muller, W. and Pollak, R. (2009) 'Nonpersistent Inequality in Educational Attainment: Evidence from Eight European Countries', American Sociological Review 114(5): 1475-521.

Breen, R. and Goldthorpe, J.H. (1997) 'Explaining Educational Differentials: Towards a Formal Rational Action Theory', Rationality and Society 9(3): 275-305.

Breen, R. and Jonsson, J.O. (2005) 'Inequality of Opportunity in Comparative Perspective: Recent Research on Educational Attainment and Social Mobility', Annual Review of Sociology 31: 223-43.

Busemeyer, M.R., Goerres, A. and Weschle, S. (2009) 'Attitudes towards Redistributive Spending in an Era of Demographic Ageing: The Rival Pressures from Age and Income in 14 OECD Countries', Journal of European Social Policy 19(3): 195-212.

Castles, F.G. (1989) 'Explaining Public Education Expenditure in OECD Nations', European Journal of Political Research 17: 431-48.

Causa, O. and Chapuis, C. (2010) 'Equity in Student Achievement Across OECD Countries: An Investigation of the Role of Policies', OECD Journal: Economic Studies 2010/1: 1-50.

Cunha, F. and Heckman, J.J. (2007) 'The Technology of Skill Formation', American Economic Review 97(2): 31-47.

Danforth, B.T. (2010) The Emergence of Three Worlds of Welfare. Prepared for the Joint NordWel and REASSESS International Summer School 2010, Odense, Denmark, 15-20 August 2010.

Deaton, A.S. and Paxson, C.H. (1998) 'Aging and Inequality in Income and Health', American Economic Review 88(2): 248-53. 
Ebbinghaus, B. and Gronwald, M. (2011) 'The Changing Public-Private Pension Mix in Europe: From Path Dependence to Path Departure' in B. Ebbingaus (ed.) The Varieties of Pension Governance. Pension Privatization in Europe, pp. 23-56. Oxford: Oxford University Press.

Esping-Andersen, G. (1990) The Three Worlds of Welfare Capitalism. Princeton, NJ: Princeton University Press.

Esping-Andersen, G. (2004) 'Untying the Gordian Knot of Social Inheritance', in A.L. Kalleberg, S.L. Morgan, J. Myles and R.A. Rosenfeld (eds) Inequality: Structures, Dynamics and Mechanisms: Essays in Honor of Aage B. Sørensen, pp. 115-138. Oxford: Elsevier.

Estevez-Abe, M., Iversen, T. and Soskice, D. (2001) 'Social Protection and the Formation of Skills: A Reinterpretation of the Welfare State', in P.A. Hall and D. Soskice (eds) Varieties of Capitalism: The Institutional Foundations of Comparative Advantage, pp. 145-83. Oxford: Oxford University Press.

Fenger, H.J.M. (2007) 'Welfare Regimes in Central and Eastern Europe: Incorporating Post-Communist Countries in a Welfare Regime Typology', Contemporary Issues and Ideas in Social Sciences 3(2): 1-30.

Ferreira, L.V. and Figueiredo, A. (2005) Welfare Regimes in the EU 15 and in the Enlarged Europe: An Exploratory Analysis. FEW Working Paper 176. Porto: Faculdade de Economia, Universidade do Porto.

Ferrera, M. (1996) 'The "Southern" Model of Welfare State in Social Europe', Journal of European Social Policy 6(1): 17-37.

Fraley, C. and Raftery, A. (1998) 'How Many Clusters? Which Clustering Method? Answers via Model-based Cluster Analysis', The Computer Journal 48(8): 578-88.

Gambetta, D. (1987) Were They Pushed or Did They Jump? Individual Decision Mechanisms in Education. Cambridge: Cambridge University Press.

Hall, P.A. and Soskice, D. (2001) 'An Introduction to Varieties of Capitalism,' in P.A. Hall and D. Soskice (eds) Varieties of Capitalism: The Institutional Foundations of Comparative Advantage, pp. 1-68. Oxford: Oxford University Press.

Hanushek, E.A. and Woessmann, L. (2006) 'Does Early Tracking Affect Educational Inequality and Performance? Differences-in-Differences Evidence across Countries', Economic Journal 116(510): C63-C76.

Heclo, H. (1985) The Welfare State in Hard Times. Washington, DC: APSA.

Heidenheimer, A.J. (1981) 'Education and Social Security Entitlements in Europe and America', in P. Flora and
A.J. Heidenheimer (eds) The Development of Welfare States in Europe and America, pp. 269-306. London: Transaction.

Hega, G.M. and Hokenmaier, K.G. (2002) 'The Welfare State and Education: A Comparison of Social and Educational Policy in Advanced Industrial Countries', German Policy Studies 2(1): 1-28.

Hicks, A. and Kenworthy, L. (2003) 'Varieties of Welfare Capitalism', Socio-Economic Review 1(1): 27-61.

Hinrichs, K. (2001) 'Elephants on the Move: Patterns of Public Pension Reform in OECD Countries', in S. Leibried (ed.) Welfare State Futures. Cambridge: Cambridge University Press.

Iversen, T. and Stephens, J.D. (2008) 'Partisan Politics, the Welfare State, and Three Worlds of Human Capital Formation', Comparative Political Studies 41(45): 600-37.

Kerckhoff, A.C. (1995) 'Institutional Arrangements and Stratification Processes in Industrial Societies', Annual Review of Sociology 21: 323-47.

Leuven, E., Lindahl, M., Oosterbeek, H. and Webbink, D. (2010) 'Expanding Schooling Opportunities for 4-year olds', Economics of Education Review 29(3): 319-28.

Lewis, J. (1992) 'Gender and the Development of Welfare Regimes', Journal of European Social Policy 2(3): 195-211.

Montolio, D. and Piolatto, A. (2011) 'Financing Public Education when Altruistic Agents Have Retirement Concerns', Documents de Treball de l'IEB. Barcelona: The Barcelona Institute of Economics.

Myles, J. and Quadagno, J. (1996) 'Recent Trends in Public Pension Reform: A Comparative View', in K.G. Banting and R. Boadway (eds) Reform of Retirement Income Policy: International and Canadian Perspectives. Kingston, Ontario: School of Policy Studies, Queen's University.

Myles, J. and Pierson, P. (2001) 'The Comparative Political Economy of Pension Reform', in P. Pierson (ed.) The New Politics of the Welfare State. Oxford: Oxford University Press.

Oesch, D. (2008) 'Stratifying Welfare States: Class Differences in Pension Coverage in Britain, Germany, Sweden and Switzerland', Swiss Journal of Sociology 34(3): 533-54.

O'Rand, A.M. (2002) 'Cumulative Advantage Theory in Life Course Research', in S. Crystal and D. Shea (eds) Annual Review of Gerontology and Geriatrics. Volume 22. New York: Springer Publishing Company. 
Organisation of Economic Co-operation and Development (2010) PISA 2009 Results: What Makes a School Successful? Volume IV. Paris: OECD.

Pechar, H. and Andres, L. (2011) 'Higher-Education Policies and Welfare Regimes: International Comparative Perspectives', Higher Education Policy 24: 25-52.

Peter, T., Edgerton, J.D. and Roberts, L.W. (2010) 'Welfare Regimes and Educational Inequality: A Cross-national Exploration', International Studies in Sociology of Education 20(3): 241-64.

Pfeffer, F.T. (2008) 'Persistent Inequality in Educational Attainment and its Institutional Context', European Sociological Review 24(5): 543-65.

Sainsbury, D. (1994) Gendering Welfare States. London: Sage Publications.

Schuetz, G., Ursprung, H.W. and Woessmann, L. (2008) 'Education Policy and Equality of Opportunity', Kyklos 61(2): 279-308.

Scruggs, L. and Allan, J.P. (2006) 'Welfare State Decommodification in Eighteen OECD Countries: A Replication and Revision', Journal of European Social Policy 16(1): 55-72.

Scruggs, L.A. and Allan, J.P. (2008) 'Social Stratification and Welfare Regimes for the Twenty-first Century: Revisiting The Three Worlds of Welfare Capitalism', World Politics 60(4): 642-64.

Scruggs, L. and Pontusson, J. (2008) 'New Dimensions of Welfare State Regimes in Advanced Democracies.' Paper presented at the 2008 Annual Meeting of the American Political Science Association, Boston, MA, 28-31 August.
Shavit, Y. and Müller, W. (1998) From School to Work: A Comparative Study of Educational Qualifications and Occupational Destinations. Oxford: Clarendon Press.

Streeck, W. (1991) 'On the Institutional Conditions of Diversified Quality Production', in E. Matzner and W. Streeck (eds) Beyond Keynesianism, pp. 21-61. Aldershot, UK: Edward Elgar.

Suzuki, R. and Shimodaira, H. (2006) 'Pvclust: An R Package for Assessing the Uncertainty in Hierarchical Clustering', Bioinformatics 22(12): 1540-2.

Vandenbroucke, F., Hemerijk, A. and Palier, B. (2011) The EU needs a social investment pact, OSE Working Paper, May.

Wilensky, H. (1975) The Welfare State and Equality. Berkeley: University of California Press.

Willemse, N. and de Beer, P. (2012) 'Three Worlds of Educational Welfare States? A Comparative Study of Higher Education Systems across Welfare States', Journal of European Social Policy 22(2): 105-17.

Woessmann, L. (2004) 'How Equal Are Educational Opportunities? Family Background and Student Achievement in Europe and the United States'. Discussion Paper 1284. Institute for the Study of Labor. Available from $\mathrm{ftp} / / / \mathrm{ftp} . i z a . o r g / \mathrm{dps} / \mathrm{dp} 1284 . \mathrm{pdf}$.

Woessmann, L. (2009) 'International Evidence on School Tracking: A Review'. CESifo DICE Report. Journal for Institutional Comparisons 7(1): 26-34.

Wolfe, J. (1970) 'Pattern Clustering by Multivariate Mixture Analysis', Multivariate Behavioral Research 5(3): 329-50.

\section{Appendix}

Table Al. Descriptive statistics.

\begin{tabular}{llcccc}
\hline Variable & $\mathrm{N}$ & Mean & Standard deviation & Minimum & Maximum \\
\hline edul & 22 & 40.35909 & 22.60867 & 7.7 & 77.3 \\
edu2 & 22 & 64.43182 & 18.94394 & 32.3 & 95.7 \\
wlmpl & 22 & 13.68955 & 5.93518 & 4.25 & 27 \\
wlmp2 & 22 & 799.8591 & 107.7058 & 548.8547 & 985 \\
wlmp3 & 22 & 5.32571 & 3.609683 & 1.843125 & 17.29938 \\
wlmp4 & 22 & 30.39045 & 50.23784 & 1.776021 & 240.9907 \\
pen1 & 22 & 168.1818 & 40.78239 & 100 & 280 \\
pen2 & 22 & 167.2727 & 31.80024 & 100 & 200 \\
pen3 & 22 & 0.619845 & 0.205879 & 0.2896309 & 0.9692979 \\
\hline
\end{tabular}

